\title{
AOR
}

Selected Papers of \#AoIR2019:

The $20^{\text {th }}$ Annual Conference of the

Association of Internet Researchers

Brisbane, Australia / 2-5 October 2019

\section{A BALANCING ACT: PUTTING UP BOOKSHELVES ON A SOCIAL MEDIA PLATFORM}

Anne-Mette Bech Albrechtslund

Independent researcher, Denmark

\section{Introduction}

This paper addresses the theme of this year's conference by focusing on the issue of trust in the uneasy relationship between content-generating users and commercially owned platforms. In this paper, I will present a case study of the use of so-called 'bookshelves' on Goodreads which offers a distinct example illustrating how a social media platform will often tests its users' trust as it seeks ways to capitalize on its users' engagement and contributions while still preserving the atmosphere of a social network built for and with its users. I focus specifically on three different examples of negotiations of trust that have emerged in relation to the platform's policies on bookshelves. The study draws particularly on discourse analysis with a focus on narrative and organizational metaphors (see e.g. Morgan, 2006), and the aim is to identify central points of ambivalence in users' attempts to balance their trust in the platform.

\section{Bookshelves on Goodreads: Inhabiting a hybrid space}

Goodreads is a very popular social network site for readers and authors, boasting 65 million users (called 'members') around the world. The discourse promoted on Goodreads emphasizes its status as a user-driven space which encourages readers to create content, an egalitarian space where the reviews posted by readers as well as the interactions between readers and authors are perceived as actually being able to 'democratize the literary system' (Vlieghe and Rutten, 2013). While Goodreads has, to some extent, been successful in creating the kind of 'participatory culture' (Jenkins, 2006) which may directly influence the publishing communication circuit (see Murray and Squires, 2013), it has also become increasingly clear in recent years that there are strong economic and strategic interests tied to the platform's business model (Moody,

Suggested Citation (APA): Albrechtslund , AM. (2019, October 2-5). A Balancing Act: Putting Up Bookshelves on A Social Media Platform. Paper presented at AolR 2019: The 20th Annual Conference of the Association of Internet Researchers. Brisbane, Australia: AolR. Retrieved from http://spir.aoir.org. 
2015; see also Kleis-Nielsen, 2018). Particularly since Goodreads was acquired by Amazon in 2013, suspicions and worries about Goodreads' increasing commercialization have been aired on Goodreads forums and elsewhere (see e.g. Albrechtslund, 2017), but as Goodreads has been a hybrid of 'community and commerce' (Bruns, 2012) since its inception, such tensions have always been present. It certainly seems that the continuing discussions on the site about the purpose of bookshelves and the policies relating to them is an indication of that.

The Goodreads 'bookshelf' is based on tags, some of which are generic, platform-generated (e.g. 'to-read') while others are user-generated and sometimes highly idiosyncratic or creative (e.g. 'let-me-fight-the-protagonist'). The purpose of bookshelves are, for most users, to organize and keep track of their reading. However, as Nakamura remarks, these digital shelves also mirror the function of physical bookshelves in our homes as a form of 'public consumption', expressing identity through taste (2013; see also Striphas, 2011). Further, Goodreads shelves constitute the kind of user-generated catalogues or 'folksonomies' (see Vander Wal, 2007) which can be seen as ways for users to name cultural resources in their own terms (Adler, 2009). Shelving practices on Goodreads are thus part of an appropriating strategy which, I suggest, shows users claiming ownership of the online space they inhabit as well as being literary curators and critics in their own right (see also Desrochers et al, 2013). In other words, bookshelves constitute a key element in making Goodreads a space users can feel 'at home' in. In the paper, I show how this becomes clear when considering users responses' to Goodreads policies on bookshelves.

\section{Case study: Three discussions on bookshelves}

I focus on three specific instances of discussions on bookshelves which have prompted articulations of trust and distrust in the Goodreads platform and its different stakeholders:

1. 'badly-behaving-authors'. In 2013, changes in Goodreads' policies on bookshelves were announced on the Goodreads forums. The changes focused on the appropriate use of bookshelf tags in relation to criticisms of author behavior and resulted in some users having shelves deleted (see also Matthews, 2015; Albrechtslund, 2017). This sparked a fierce discussion of the platform's role as a marketing tool for authors and publishers, and users' contributions to the platform being exploited to this end.

2. Private shelves. The ability to set some bookshelves as 'private' (for various reasons) has been a request from users since 2008 . This has been continuously rejected by Goodreads, and users have resorted to workarounds to have private shelves. In discussion threads about the issue, different understandings of the expectations of privacy, intended audiences, and relationship between users emerge.

3. The giveaways program. One of the ways publishers and authors can use Goodreads to promote their books is by setting up giveaway contests. In 2017, changes to the US giveaways program were announced by Goodreads product manager. One of the changes directly influenced users' control of their bookshelves, as users entering a giveaway contest for a book would now have the book automatically added to their 
'want-to-read' shelf. This prompted several discussions on the function of bookshelves and users' control over them.

It must be stressed that users are certainly not naive about the fact that their content is being used for marketing, nor is Goodreads being secretive about it. As this paper shows, policies on bookshelves prompt users to negotiate this community/commerce hybridity (see Bruns, 2012) which requires an ongoing balancing act for users to feel comfortable entrusting the platform with their content.

\section{References}

Albrechtslund, A.-M. B. (2017). Negotiating ownership and agency in social media: Community reactions to Amazon's acquisition of Goodreads. First Monday, 22(5).

Adler, M. (2009). Transcending Library Catalogs: A Comparative Study of Controlled Terms in Library of Congress Subject Headings and User-Generated Tags in LibraryThing for Transgender Books. Journal of Web Librarianship, 3(4), 309-331.

Bruns, A. (2012). Reconciling Community and Commerce? Information, Communication \& Society, 15(6), 815-835.

Desrochers, N., Quan-Haase, A., Pennington, D. R., Laplante, A., Martin, K., \& Spiteri, L. (2013). Beyond the playlist: Looking at user-generated collocation of cultural products through social tagging. Proceedings of the American Society for Information Science and Technology, 50(1), 1-4.

DeVito, M. A., Birnholtz, J., \& Hancock, J. T. (2017). Platforms, People, and Perception: Using Affordances to Understand Self-Presentation on Social Media. In Proceedings of the 2017 ACM Conference on Computer Supported Cooperative Work and Social Computing (pp. 740-754). New York, NY, USA: ACM.

Jenkins, H. (2006). Convergence Culture: Where Old and New Media Collide. NYU Press.

Kleis-Nielsen, R. (2018). Lecture: The Power of Platforms. Retrieved February 27, 2019, from https://reutersinstitute.politics.ox.ac.uk/risj-review/lecture-power-platforms

Matthews, J. C. (2015). Professionals and nonprofessionals on Goodreads: Behavior standards for authors, reviewers, and readers. New Media \& Society.

Moody, S. (2017). Bullies and blackouts: Examining the participatory culture of online book reviewing. Convergence.

Morgan, G. (2010 (2006)). Images of organization. Thousand Oaks: Sage Publications. 
Murray, P. R., \& Squires, C. (2013). The digital publishing communications circuit. Book 2.0.

Nakamura, L. (2013). "Words with Friends": Socially Networked Reading on Goodreads. $P M L A, 128(1), 238-243$.

Striphas, T. (2011). The Late Age of Print: Everyday Book Culture from Consumerism to Control. Columbia University Press.

Vander Wal, T. (2007). Folksonomy Coinage and Definition. Retrieved from http://www.vanderwal.net/folksonomy.html

Vlieghe, J., \& Rutten, K. (2013). Rhetorical Analysis of Literary Culture in Social Reading Platforms. CLCWeb: Comparative Literature and Culture, 15(3).

Webster, L., \& Mertova, P. (2007). Using narrative inquiry as a research method: an introduction to using critical event narrative analysis in research on learning and teaching. Routledge. 